\title{
Identification and lactic acid production of bacteria isolated from soils and tree barks
}

\author{
Vasana Tolieng $^{1}$, Budsabathip Prasirtsak ${ }^{1}$, Jaruwan Sitdhipol ${ }^{2}$, Nuttha Thongchul ${ }^{1}$ and Somboon Tanasupawat ${ }^{3^{*}}$ \\ ${ }^{1}$ Institute of Biotechnology and Genetic Engineering, Chulalongkorn University, Bangkok 10330, Thailand. \\ ${ }^{2}$ Bioscience Department, Thailand Institute of Scientific and Technological Research (TISTR), PathumThani 12120, \\ Thailand. \\ Department of Biochemistry and Microbiology, Faculty of Pharmaceutical Sciences, Chulalongkorn University, Bangkok \\ 10330, Thailand. \\ E-mail: Somboon.T@chula.ac.th
}

Received 8 August 2016; Received in revised form 7 October 2016; Accepted 13 October 2016

\begin{abstract}
Aims: The objective of this research was to isolate and identify lactic acid producing bacteria from soils and tree barks in Thailand. Their acid production was also determined.

Methodology and results: Eleven bacterial strains isolated from soils and tree barks were screened for their lactic acid production. They were divided into 4 groups based on their phenotypic characteristics and 16S rRNA gene sequence analyses. Group I (3 isolates) identified as Lactococcus produced L-lactic acid ranged from $72.32 \pm 0.707-77.47 \pm 0.184$ $\mathrm{g} / \mathrm{L}$, yield of $0.96 \pm 0.011-1.06 \pm 0.008 \mathrm{~g} / \mathrm{g}$, productivity of $1.00 \pm 0.010-1.08 \pm 0.003 \mathrm{~g} / \mathrm{L} . \mathrm{h}$ and optical purity was $100 \%$. Group II (3 isolates) identified as Enterococcus hirae, produced L-lactic acid ranged from $31.56 \pm 0.424-34.86 \pm 0.283$ $\mathrm{g} / \mathrm{L}$, yield of $1.06 \pm 0.008-1.23 \pm 0.036 \mathrm{~g} / \mathrm{g}$, productivity of $0.44 \pm 0.006-0.48 \pm 0.004 \mathrm{~g} / \mathrm{L}$.h and optical purity was 98.6 $100 \%$. Group III (3 isolates) identified as Bacillus coagulans, produced L-lactic acid ranged from 48.48 $\pm 0.283-93.51 \pm$ $0.552 \mathrm{~g} / \mathrm{L}$, yield of $1.00 \pm 0.001-1.07 \pm 0.005 \mathrm{~g} / \mathrm{g}$, productivity of $0.67 \pm 0.004-1.30 \pm 0.008 \mathrm{~g} / \mathrm{L} . \mathrm{h}$ and high optical purity of the tested isolate was $99.56 \%$. Group IV (2 isolates) identified as Sporoactobacillus. Only NN2 produced D-lactic acid concentration $87.64 \pm 0.375 \mathrm{~g} / \mathrm{L}$, yield of $0.83 \pm 0.000 \mathrm{~g} / \mathrm{g}$, productivity of $1.22 \pm 0.005 \mathrm{~g} / \mathrm{L} . \mathrm{h}$ and optical purity was $96.16 \%$. All isolates produced lactic acid when $120 \mathrm{~g} / \mathrm{L}$ of the initial glucose was used as a substrate.

Conclusion, significance and impact of study: Lactic acid producing bacteria are isolated from soils and tree barks. The coccal isolates could produce high L-lactic acid concentration with high optical purity while the spore-forming isolates produces L- and D-lactic acid which are useful for food preservation, chemical in pharmaceutical, cosmetic and textile industries.
\end{abstract}

Keywords: Bacillus, Enterococcus, Lactococcus, Sporolactobacillus, lactic acid

\section{INTRODUCTION}

Lactic acid (2-hydroxypropionic acid or $\mathrm{CH}_{3} \mathrm{CHOHCOOH}$ ) can be produced via chemical synthesis or microbial fermentation. Chemical synthesis requires petroleum feedstocks and yields the racemic mixtures of lactic acid while microbial fermentation utilizes the renewable feedstocks which low cost substrate to produce an optically pure L-or D-lactic acid depending on the organism under mild conditions resulting in low energy consumption. Lactic acid bacteria present their ability to produce $\mathrm{D}, \mathrm{L}$, and DL-lactic acid, depending on their lactate dehydrogenases and racemases. It had been reported that L-lactic acid was produced in Enterococcus species, Lactobacillus species, $B$. coagulans, $B$. subtilis and Lactococcus species (Hujanen and Linko, 1996; Michelson et al., 2006; Chen et al., 2013; Gao and Ho,
2013; Yokaryo and Tokiwa, 2014). Pure isomers of L- or $\mathrm{D}$-lactic acid, are more valuable than the racemic $\mathrm{DL}$ form because each isomer has many applications in diverse industries such as an acidulant, flavour enhancer, preservative in the food, cosmetics, pharmaceutical, leather, textile industries and a monomer building block of the biodegradable plastic (Wee et al., 2006; John et al., 2009; Xu et al., 2010; Sobrun et al., 2012).

Recently, the current demand of L-lactic acid is increasing due to the increasing trend of replacing petroleum based plastic by biobased plastic derived from plant materials such as polylactic acid (PLA) (Wee et al., 2006). Therefore, this study deals with the isolation and identification of lactic acid producing bacteria that exhibit high lactic acid production and optical purity from soil and 
Table 1: Samples, location, isolate number, group, 16SrRNA gene sequence similarity (\%) and identification.

\begin{tabular}{|c|c|c|c|c|c|}
\hline Samples & Province & $\begin{array}{l}\text { Isolate } \\
\text { no. }\end{array}$ & Group & $\begin{array}{l}\% \\
\text { Similarity }\end{array}$ & Identification \\
\hline Bark of $M$. indica L. & Bangkok & BK12-1 & I & 100 & L.lactis subsp. lactis \\
\hline Soil & Mahasarakham & MK29-2 & I & 99.93 & L. taiwanensis \\
\hline Soil & Mahasarakham & MK29-3 & I & 99.85 & L. taiwanensis \\
\hline Soil & Saraburi & SB6-2 & II & 99.3 & E. hirae \\
\hline Bark of $A$. crassna Pierre ex $\mathrm{H}$. Lec. & Bangkok & BK10-1 & II & 99.93 & E. hirae \\
\hline Soil & Bangkok & BK13-1 & II & 100 & E. hirae \\
\hline Bark of S. saman (Jacq.) Merr. & Bangkok & BK9-1 & III & 99.39 & B. coagulans \\
\hline Bark of S. saman (Jacq.) Merr. & Bangkok & BK9-2 & III & 99.38 & B. coagulans \\
\hline Bark of S. saman (Jacq.) Merr. & Bangkok & BK9-3 & III & 99.48 & B. coagulans \\
\hline Soil & Nakhon Nayok & NN2 & IV & 99.93 & S. laevolacticus \\
\hline Soil & Nakhon Nayok & NN3-1 & IV & 99.99 & S. spathodeae \\
\hline
\end{tabular}

tree barks in Thailand.

\section{MATERIALS AND METHODS}

\section{Sources and isolation methods}

The soils collected from Mahasarakham, Saraburi, Nakhon Nayok, Bangkok provinces, and the bark of trees including Mangifera indica L., Aquilaria crassna Pierre ex H. Lec., Samanea saman (Jacq.) Merr collected from Bangkok, Thailand were used for the bacterial isolation (Table 1). A $0.25 \mathrm{~g}$ of sample was enriched in $5 \mathrm{~mL}$ Glucose-Yeast extract-Peptone (GYP) broth (Prasirtsak et al., 2013) containing (per liter) $10 \mathrm{~g}$ glucose, $5 \mathrm{~g}$ yeast

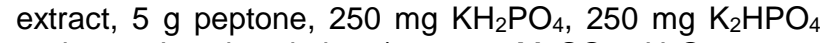
and $10 \mathrm{~mL}$ salt solution $\left(400 \mathrm{mg} \mathrm{MgSO} 4 \cdot 7 \mathrm{H}_{2} \mathrm{O}, 20 \mathrm{mg}\right.$ $\mathrm{MnSO}_{4} \cdot 5 \mathrm{H}_{2} \mathrm{O}, 20 \mathrm{mg} \mathrm{FeSO} \cdot \cdot 7 \mathrm{H}_{2} \mathrm{O}$ and $20 \mathrm{mg} \mathrm{NaCl}$ per $100 \mathrm{~mL}$ solution) and incubated under anaerobic conditions at $37^{\circ} \mathrm{C}$ for 3 days. The isolates were streaked on GYP agar plate containing $\mathrm{CaCO}_{3}(0.5 \%)$ and incubated at the same temperature until the colonies were developed. They were purified and kept on GYP agar slant for further study.

\section{Identification methods}

\section{Phenotypic characterization}

Phenotypic characteristics such as morphological and cultural of the isolates were investigated on GYP agar plate containing $\mathrm{CaCO}_{3}$ as acid production indicator, after incubated under anaerobic conditions at $37^{\circ} \mathrm{C}$ for 3 days. Gram reaction, spore formation, gas formation, catalase activity, nitrate reduction, hydrolysis of arginine and starch, growth at different temperatures $\left(10-50{ }^{\circ} \mathrm{C}\right)$, at different $\mathrm{pH}$ values (4-8.5) and different $\mathrm{NaCl}$ concentrations $(\mathrm{w} / \mathrm{v})$ were performed as previously described (Tanasupawat et al., 1992; Tanasupawat et al., 1998). Cell shape and spore formation were observed under the light microscope and scanning electron microscope (JSM-5410LV and JSM-6610LV, Tokyo, Japan). Acid formation from various carbohydrates were tested as previously described (Tanasupawat et al., 1998). The isomer of lactic acid was analyzed by using high-performance liquid chromatography (Prasirtsak et al., 2013).

\section{Genotypic characterization}

The 16SrRNA gene was PCR amplified using primers 27F (5'-AGAGTTTGATCMTGGCTCAG-3'), 518F (5'CCAGCAGCCGCGGTAATACG-3'), 800R (5'TACCAGGGTATCTAATCC-3') and 1492R (5'TACGGYTACCTTGTTACGACTT-3') and the amplified 16SrRNA gene sequence was analyzed by Macrogen ${ }^{\circledR}$, Korea. The sequences of strain were aligned with selected sequences obtained from GenBank by using CLUSTAL_X version 1.81. The alignment was edited manually to remove gaps and ambiguous nucleotides prior to the construction of phylogenetic trees. A phylogenetic tree was constructed by the neighbor joining method (Saitou and Nei, 1987) with the program MEGA 6 (Tamura et al., 2013). The confidence values of individual branches in the phylogenetic tree were determined by using the bootstrap analysis of (Felsenstein, 1985) based on 1000 replications. The values for sequence similarity among the closest strains were determined using the EzTaxon server (Kim et al., 2012).

\section{Determination of lactic acid and end product}

The bacterial isolates were divided into two groups based on the catalase activity. First group, catalase negative isolates were subcultured on the freshly new GYP agar slant and incubated at $37^{\circ} \mathrm{C}$ for $48 \mathrm{~h}$ under anaerobic condition. The preculture flask consisting of (per liter $10 \mathrm{~g}$ glucose, $5 \mathrm{~g}$ yeast extract, $5 \mathrm{~g}$ peptone, $0.25 \mathrm{~g} \mathrm{KH}_{2} \mathrm{PO}_{4}$, $0.25 \mathrm{~g} \mathrm{~K}_{2} \mathrm{HPO}_{4}, 5 \mathrm{~g} \mathrm{CaCO}_{3}$ and $10 \mathrm{~mL}$ salts solution) was incubated at $37^{\circ} \mathrm{C}$ under anaerobic condition for $26 \mathrm{~h}$. Later $1 \mathrm{~mL}$ preculture broth was inoculated into $49 \mathrm{~mL}$ fermentation medium ( $\mathrm{pH}$ 6.80) consisting of (per liter) $120 \mathrm{~g}$ glucose, $20 \mathrm{~g}$ yeast extract, $10 \mathrm{~g}$ peptone, $0.50 \mathrm{~g}$ $\mathrm{KH}_{2} \mathrm{PO}_{4}, 0.50 \mathrm{~g} \mathrm{~K}_{2} \mathrm{HPO}_{4}$, and $20 \mathrm{~mL}$ salts solution. After that $4 \mathrm{~g} \mathrm{CaCO}_{3}$ was added into the culture broth. The second group, catalase positive isolates were subcultured on the freshly new GYP agar slant and incubated at $37^{\circ} \mathrm{C}$ for $48 \mathrm{~h}$ under aerobic condition. The preculture flask consisting of (per liter $10 \mathrm{~g}$ glucose, $15 \mathrm{~g}$ yeast extract, 4 
$\mathrm{g} \mathrm{NH}_{4} \mathrm{Cl}, 0.50 \mathrm{~g} \mathrm{KH}_{2} \mathrm{PO}_{4}, 0.50 \mathrm{~g} \mathrm{~K}_{2} \mathrm{HPO}_{4}, 5 \mathrm{~g} \mathrm{CaCO}_{3}$ and $20 \mathrm{~mL}$ salts solution) was incubated at $37^{\circ} \mathrm{C}$ and shaked/swirled at $200 \mathrm{rpm}$ for $5 \mathrm{~h}$. Later $25 \mathrm{~mL}$ preculture broth is transferred into $25 \mathrm{~mL}$ glucose solution $(240 \mathrm{~g} / \mathrm{L})$ containing $4 \mathrm{~g} \mathrm{CaCO}_{3}$. They were incubated at $37^{\circ} \mathrm{C}$ for $72 \mathrm{~h}$ under ambient condition. At the end of fermentation, the supernatant was analyzed of lactic acid and the residual glucose by high-performance liquid chromatography (HPLC; Biorad, Aminex HPX-87H ion exclusion organic acid column, $300 \mathrm{~mm} \times 7.8 \mathrm{~mm}$ ) maintained at $45{ }^{\circ} \mathrm{C}$ in a column oven (Shimadzu-CTO$6 \mathrm{~A})$. An eluent, $0.005 \mathrm{M} \mathrm{H}_{2} \mathrm{SO}_{4}$, was pumped through the system at the flow rate of $0.6 \mathrm{~mL} / \mathrm{min}$ (Shimadzu-LC10Avp). A refractive index detector (Shimadzu-RID-10A) was used to detect the organic compounds detail.

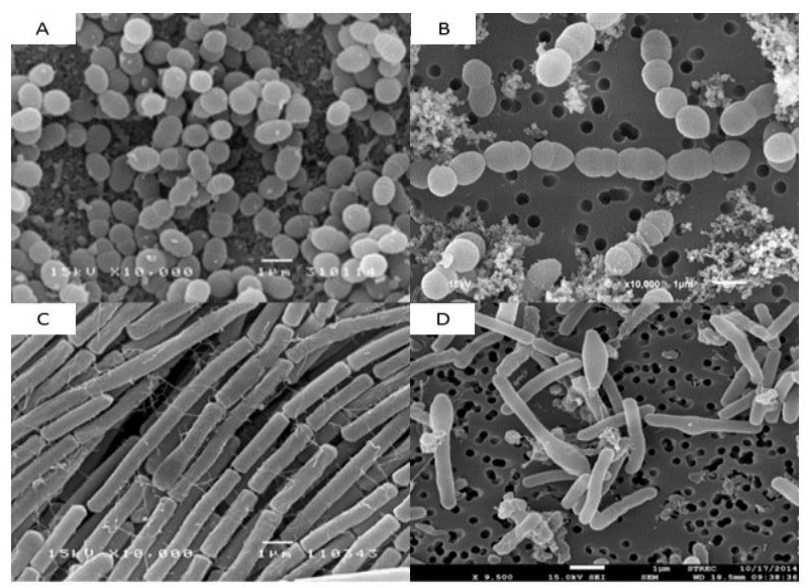

Figure 1: Scanning electron micrograph of isolates BK121 (Group I), A; BK13-1 (Group II), B; BK9-1 (Group III), C; and NN2 (Group IV), D on GYP agar plates.

\section{RESULTS AND DISCUSSION}

\section{Identification}

Six coccal isolates, Gram-positive and non-spore forming bacteria and 5 Gram-positive and spore forming bacteria were characterized. They showed negative reaction to catalase activity (except 3 isolates of Bacillus), nitrate reduction and hydrolysis of starch. They were homofermentative lactic acid bacteria with high optical purity of lactic acid from glucose fermentation. All isolates were divided into four groups based on the cell form, spore formation, growth at different temperatures and $\mathrm{pH}$, and $\mathrm{NaCl}$ concentrations and acid production from various carbohydrates (Tables 1 and 2) including 16SrRNA gene sequence analyses (Figures 2 and 3). Group I consisted of an isolate BK12-1, MK29-2 and MK29-3. Cells were cocci in chain and non-spore forming (Figure 1). Colonies were smooth, circular, convex, and ivory-white in colour (1.0-1.5 $\mathrm{mm}$ in diameter). The isolate
Table 2: Phenotypic characteristics of the isolates.

\begin{tabular}{|c|c|c|c|c|}
\hline Characteristics & 1 & II & III & IV \\
\hline No. of isolates & 3 & 3 & 3 & 2 \\
\hline Cell form & Cocci & Cocci & Rods & Rods \\
\hline Spore formation & - & - & + & + \\
\hline Growth temp. $\left({ }^{\circ} \mathrm{C}\right)$ & $20-45$ & $15-45$ & $20-50$ & $25-40$ \\
\hline Growth in $\mathrm{NaCl}(\%)$ & 5 & 7 & 5 & 7 \\
\hline Growth at pH & $4.5-8.5$ & $5.5-8.5$ & $4.5-8.5$ & $4.5-8.5$ \\
\hline Catalase activity & - & - & + & - \\
\hline Nitrate reduction & - & - & $-(w 1)$ & - \\
\hline Starch hydrolysis & - & - & - & - \\
\hline Arginine hydrolysis & $-(+1)$ & - & - & $w(-1)$ \\
\hline \multicolumn{5}{|l|}{ Acid from: } \\
\hline L-Arabinose & + & $-(+1)$ & + & $+(-1)$ \\
\hline D-Cellobiose & + & + & + & + \\
\hline Dextran & - & $-(+1)$ & - & + \\
\hline D-Fructose & + & + & + & + \\
\hline D-Galactose & + & + & + & $+(-1)$ \\
\hline Inulin & - & $-(+1)$ & $-(w 1)$ & + \\
\hline Lactose & + & + & $+(-1)$ & $-(+1)$ \\
\hline D-Maltose & + & + & + & $-(+1)$ \\
\hline D-Mannitol & + & $-(+1)$ & $+(-1)$ & $-(+1)$ \\
\hline D-Mannose & + & + & + & + \\
\hline D-Melibiose & $-(+1)$ & + & $+(-1)$ & + \\
\hline Raffinose & - & $-(+1)$ & $-(+1)$ & + \\
\hline D-Sorbitol & - & $-(+1)$ & $-(+1)$ & - \\
\hline L-Sorbose & - & $-(+1)$ & $-(+1)$ & + \\
\hline Sucrose & + & + & + & + \\
\hline D-Trehalose & + & + & + & + \\
\hline D-Xylose & + & - & + & + \\
\hline Isomer of lactic acid & $\mathrm{L}$ & $\mathrm{L}$ & $\mathrm{L}$ & $\mathrm{D}$ \\
\hline
\end{tabular}

+, positive reaction; -, negative reaction; $\mathrm{w}$, weak reaction. Numbers in parentheses indicate the number of isolates showing the reaction.

grew at $20-45{ }^{\circ} \mathrm{C}$, at $\mathrm{pH} 4.5-8.5$ and in $5 \% \mathrm{NaCl}$. Only one isolate BK12-1 could hydrolyze arginine. Acid was produced from L-arabinose, D-cellobiose, D-fructose, Dgalactose, D-glucose, lactose D-maltose, D-mannitol, Dmannose, sucrose, D-trehalose and D-xylose but did not produce acid from dextran, inulin, raffinose, sorbitol and L-sorbose. Some isolates were variable on acid production from D-melibiose (Table 2). The 16S rRNA gene sequence of isolate BK12-1 showed $100 \%$ similarity to Lactococcus lactis subsp.lactis $\mathrm{JCM} 5805^{\top}$. Isolates MK29-2 and MK29-3 showed $99.9-100 \%$ similarity to Lactococcus taiwanensis 0905C15 $5^{\top}$ (Figure 2). Therefore, isolate BK12-1 was identified as $L$. lactis subsp.lactis 


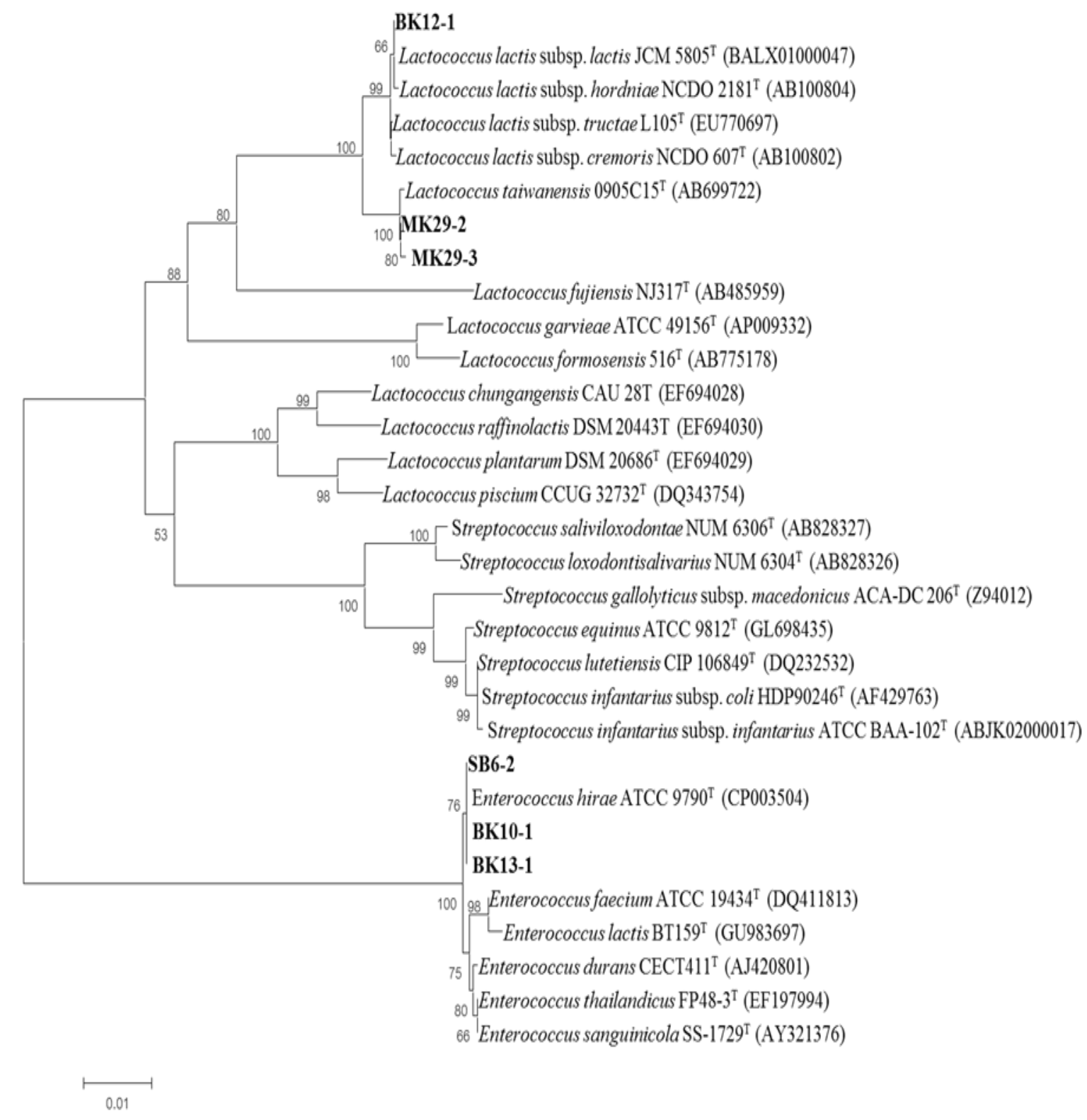

Figure 2: Phylogenetic tree constructed using the neighbor-joining method showing the position of Lactococcus and Enterococcus isolates and related species based on 16S rRNA gene sequences. 


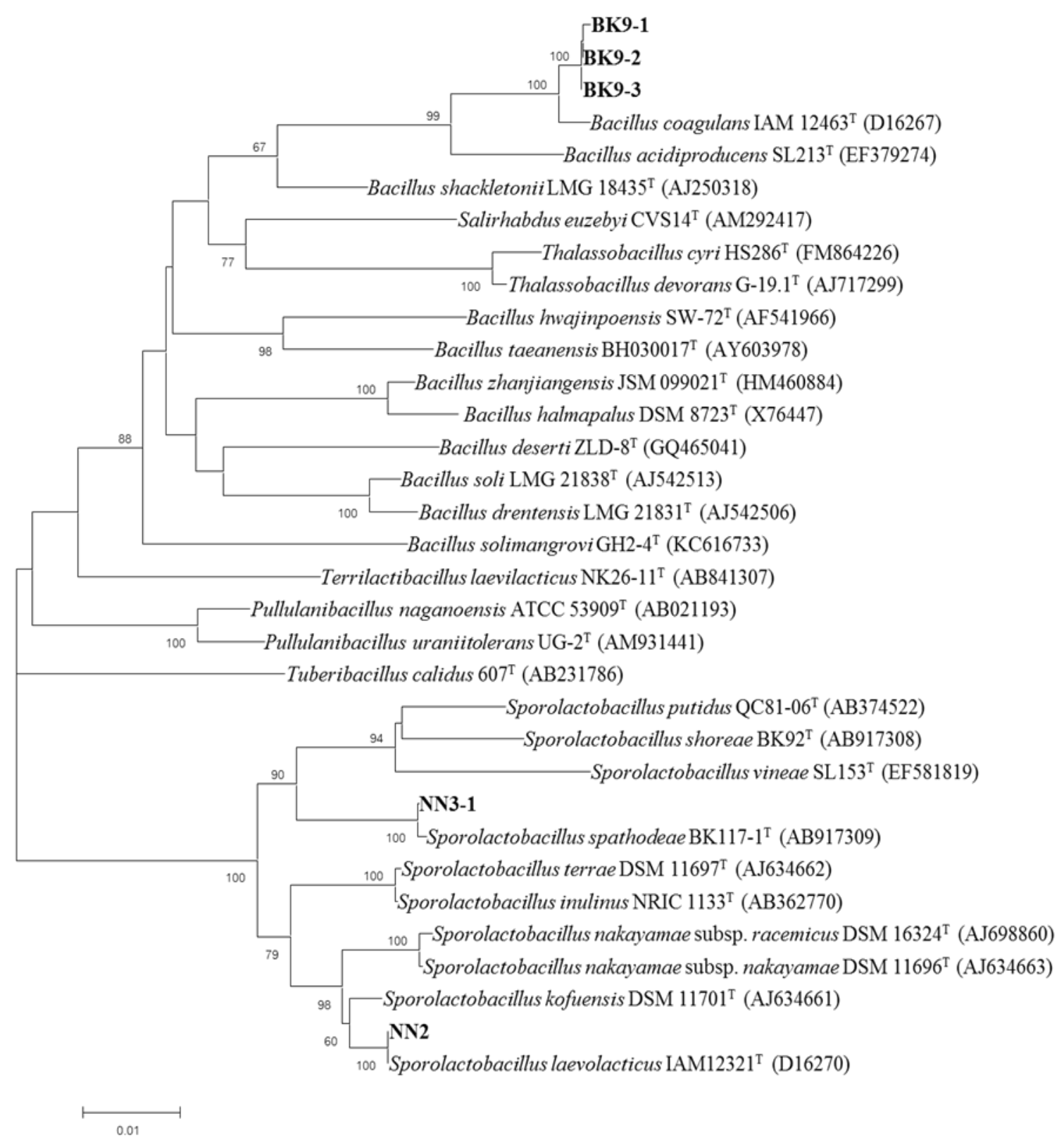

Figure 3: Phylogenetic tree constructed using the neighbor-joining method showing the position of Bacillus and Sporolactobacillus isolates and related species based on 16S rRNA gene sequences. 


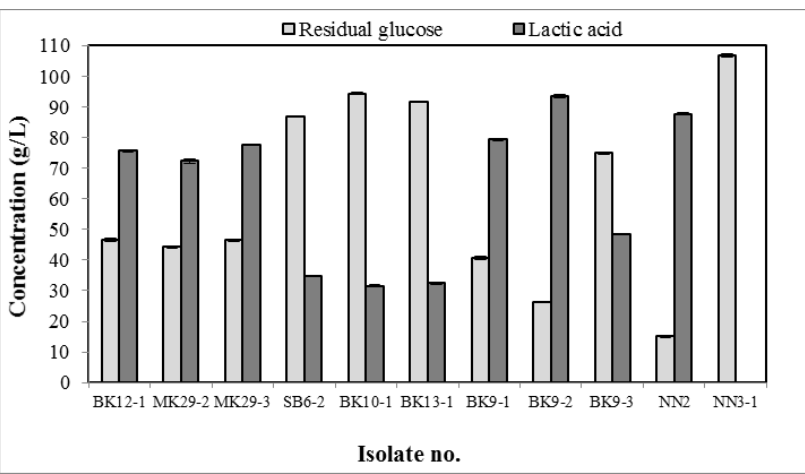

Figure 4: Lactic acid fermentation and residual glucose of isolates.

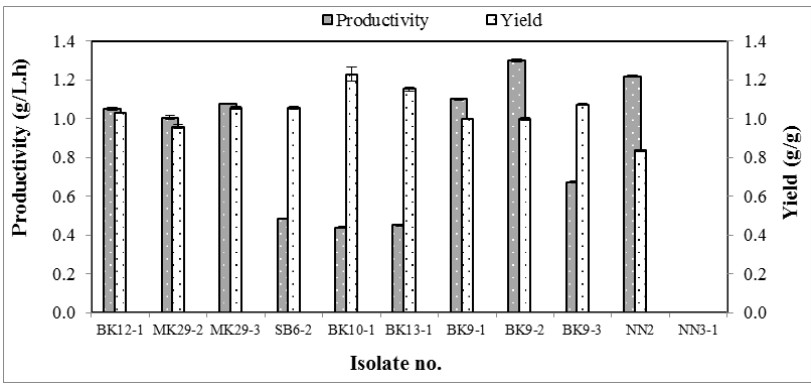

Figure 5: Yields and productivity of lactic acid of isolates cultivated in GYP medium containing $120 \mathrm{~g} / \mathrm{L}$ glucose at $37^{\circ} \mathrm{C}, 72 \mathrm{~h}$.

(Fujii et al., 2015) while isolates MK29-2 and MK29-3 were L. taiwanensis (Chen et al., 2013).

Group II consisted of an isolate SB6-2, BK10-1 and BK13-1. Cells were cocci in chains and non-spore forming (Figure 1). Colonies were smooth, circular, convex, and ivory-white in colour $(0.4-4.0 \mathrm{~mm}$ in diameter). The isolate grew at $15-45{ }^{\circ} \mathrm{C}$, at $\mathrm{pH} 5.5-8.5$ and in $7 \% \mathrm{NaCl}$. They showed negative reaction on nitrate reduction and hydrolysis of arginine. Acid was produced from Dcellobiose, D-fructose, D-galactose, D-glucose, Dmaltose, D-mannose, D-melibiose, sucrose and Dtrehalose. Some isolates produced acid from L-arabinose, dextran, inulin, lactose, D-mannitol, raffinose, sorbitol, and L-sorbose (Table 2). The 16S rRNA gene sequence of these isolates showed $99.3-100 \%$ similarity to $E$. hirae ATCC $9790^{\top}$ (Figure 2). Therefore, they were identified as E. hirae (Farrow and Collins, 1985; Devriese et al., 2006).

Group III consisted of three isolates, BK9-1, BK9-2 and BK9-3. Cells were spore- forming rods (Figure 1). Colonies were smooth, circular, convex, and ivory-white in colour (1.0-3.1 $\mathrm{mm}$ in diameter). These isolates produced catalase, grew at $20-50^{\circ} \mathrm{C}$, at $\mathrm{pH} 4.5-8.5$ and in $5 \% \mathrm{NaCl}$. Acid was produced from L- arabinose, Dcellobiose, D-fructose, D-galactose, D-glucose, Dmaltose, D-mannose, sucrose, D-trehalose and D-xylose but did not produce acid from dextran. Some isolates produced acid from inulin, lactose, D-mannitol, Dmelibiose, raffinose, D-sorbitol and L-sorbose. The $16 \mathrm{~S}$
rRNA gene sequence of isolates showed 99.4-99.5\% similarity to $B$. coagulans IAM $12463^{\top}$ (Figure 3). Therefore, they were identified as $B$. coagulans (Nakamura et al., 1988).

Group IV consisted of two isolates, NN2 and NN3-1. Cells were spore-forming rods (Figure 1). Colonies were smooth, circular, convex, and ivory-white in colour (1.3$2.4 \mathrm{~mm}$ in diameter). The isolates grew at $25-40{ }^{\circ} \mathrm{C}$, at $\mathrm{pH}$ 4.5.0-8.5 and in $7 \% \mathrm{NaCl}$. One isolate hydrolysed arginine weakly. Acid was produced from D-cellobiose, dextran, D-fructose, D-glucose, inulin, D-mannose, Dmelibiose, raffinose, L-sorbose, sucrose, D-trehalose and $\mathrm{D}$-xylose but one produced acid from L-arabinose, Dgalactose, lactose, D-maltose and D-mannitol while all did not produce acid from D-sorbitol (Table 2). The 16S rRNA gene sequence of isolate NN2 showed $99.93 \%$ similarity to Sporolactobacillus laevolacticus IAM $12321^{\top}$ (Figure 3). Therefore, it was identified as $S$. laevolacticus (Ludwig et al., 2009). The 16S rRNA gene sequence of isolate NN31 showed $99.99 \%$ similarity to $S$. spathodeae (Figure 3). Therefore, they were identified as $S$. laevolacticus and $S$. spathodeae, respectively (Thamacharoensuk et al., 2015).

\section{Lactic acid production}

The results on the qualitative isomer of $\mathrm{L}$-and $\mathrm{D}$-lactic acid by using HPLC were shown in Table 3, Figures 4 and 5. Lactococcus lactis subsp. lactis BK12-1 in Group I which gave final lactic acid concentration $75.67 \pm 0.424$ $\mathrm{g} / \mathrm{L}$, productivity $1.05 \pm 0.006 \mathrm{~g} / \mathrm{L} . \mathrm{h}$, yield $1.03 \pm 0.000 \mathrm{~g} / \mathrm{g}$ and optical purity of L-lactic acid $100 \%$ while $L$. taiwanensis MK29-3 produced final lactic acid concentration $77.47 \pm 0.184$, productivity $1.08 \pm 0.003$ g/L.h, yield $1.06 \pm 0.008 \mathrm{~g} / \mathrm{g}$ and optical purity of L-lactic acid $100 \%$. L. lactis subsp. lactis and $L$. taiwanensis strains were reported to isolate from fresh cummingcordia and leaves of sugar cane plant (Cock and de Stouvenel, 2006; Chen et al., 2013). A comparison of our strains, LC. lactis $10-1$ was reported to produce final lactic acid concentration $7 \mathrm{~g} / \mathrm{L}$, productivity $0.11 \mathrm{~g} / \mathrm{L} . \mathrm{h}$ and yield $26 \%$ using sugarcane bagasse hydrolysate by batch fermentation (Laopaiboonet al., 2010) while L. lactis subsp. lactis could produce lactic acid from $60 \mathrm{~g} / \mathrm{L}$ of glucose by batch fermentation, $32 \mathrm{~g} / \mathrm{L}$ of lactic acid, $63 \%$ of yield and $0.67 \mathrm{~g} / \mathrm{L} . \mathrm{h}$ of productivity were obtained (Cock and de Stouvenel, 2006).

Group II, isolates SB6-2, BK10-1 and BK13-1 identified as $E$. hirae produced lactic acid range from $31.56 \pm 0.424-34.86 \pm 0.283 \mathrm{~g} / \mathrm{L}$, yield of $1.06 \pm 0.008-1.23$ $\pm 0.036 \mathrm{~g} / \mathrm{g}$, productivity of $0.44 \pm 0.006-0.48 \pm 0.004 \mathrm{~g} / \mathrm{L} . \mathrm{h}$ and optical purity was $98.61-100 \%$. It had been reported that $E$. hirae was isolated from raw waste water and tree bark which was obtainedfinal L-lactic acid, productivity and yield were $66.04 \mathrm{~g} / \mathrm{L}, 0.92 \mathrm{~g} / \mathrm{L} . \mathrm{h}$ and $70 \%$, respectively (Prasirtsak et al., 2013) while L-lactic acid producing strains were isolated from fermented fish products and elephant faeces in Thailand (Tanasupawat et al., 1998; Thamacharoensuk et al., 2013). 
Table. 3: Lactic acid and residual glucose of isolates.

\begin{tabular}{|c|c|c|c|c|c|c|c|}
\hline \multirow{2}{*}{$\begin{array}{l}\text { Isolate } \\
\text { no. }\end{array}$} & \multirow[b]{2}{*}{ Group } & \multicolumn{3}{|c|}{ Lactic acid } & \multirow{2}{*}{$\begin{array}{l}\text { Initial } \\
\text { glucose } \\
(\mathrm{g} / \mathrm{L})\end{array}$} & \multirow{2}{*}{$\begin{array}{l}\text { Residual } \\
\text { glucose } \\
(\mathrm{g} / \mathrm{L})\end{array}$} & \multirow{2}{*}{$\begin{array}{c}\text { Optical purity } \\
\text { of lactic acid } \\
\text { (\%ee.) }\end{array}$} \\
\hline & & $\begin{array}{c}\text { Final lactic acid } \\
(\mathrm{g} / \mathrm{L})\end{array}$ & $\begin{array}{l}\text { Yield } \\
(\mathrm{g} / \mathrm{g})\end{array}$ & $\begin{array}{l}\text { Productivity } \\
\text { (g/L.h) }\end{array}$ & & & \\
\hline BK12-1 & I & $75.67 \pm 0.424$ & $1.03 \pm 0.000$ & $1.05 \pm 0.006$ & 120 & $46.49 \pm 0.537$ & (L) 100.00 \\
\hline MK29-2 & I & $72.32 \pm 0.707$ & $0.96 \pm 0.011$ & $1.00 \pm 0.010$ & 120 & $44.33 \pm 0.410$ & (L) 100.00 \\
\hline MK29-3 & I & $77.47 \pm 0.184$ & $1.06 \pm 0.008$ & $1.08 \pm 0.003$ & 120 & $46.55 \pm 0.424$ & (L) 100.00 \\
\hline SB6-2 & II & $34.86 \pm 0.283$ & $1.06 \pm 0.008$ & $0.48 \pm 0.004$ & 120 & $86.92 \pm 0.092$ & (L) 98.61 \\
\hline BK10-1 & II & $31.56 \pm 0.424$ & $1.23 \pm 0.036$ & $0.44 \pm 0.006$ & 120 & $94.31 \pm 0.417$ & (L) 100.00 \\
\hline BK13-1 & II & $32.49 \pm 0.354$ & $1.15 \pm 0.010$ & $0.45 \pm 0.005$ & 120 & $91.76 \pm 0.141$ & (L) 100.00 \\
\hline BK9-1 & III & $79.34 \pm 0.361$ & $1.00 \pm 0.001$ & $1.10 \pm 0.005$ & 120 & $40.70 \pm 0.495$ & (L) 99.56 \\
\hline BK9-2 & III & $93.51 \pm 0.552$ & $1.00 \pm 0.007$ & $1.30 \pm 0.008$ & 120 & $26.37 \pm 0.092$ & ND \\
\hline BK9-3 & III & $48.48 \pm 0.283$ & $1.07 \pm 0.005$ & $0.67 \pm 0.004$ & 120 & $74.95 \pm 0.354$ & ND \\
\hline NN2 & IV & $87.64 \pm 0.375$ & $0.83 \pm 0.000$ & $1.22 \pm 0.005$ & 120 & $15.12 \pm 0.424$ & (D) 96.16 \\
\hline NN3-1 & IV & $50.69 \pm 1.021$ & $0.51 \pm 0.021$ & $0.70 \pm 0.026$ & 80 & $21.47 \pm 0.982$ & (D) 98.80 \\
\hline NN3-1 & IV & $14.23 \pm 1.382$ & $0.30 \pm 0.022$ & $0.20 \pm 0.025$ & 100 & $72.74 \pm 0.862$ & (D) 94.38 \\
\hline NN3-1 & IV & $0.00 \pm 0.000$ & $0.00 \pm 0.000$ & $0 \pm 0.000$ & 120 & $106.69 \pm 0.559$ & ND \\
\hline
\end{tabular}

ND, not determined.

The isolates BK9-1 and BK9-3 in Group III identified as $B$. coagulans, produced final lactic acid range from $79.34 \pm 0.361$ and $48.48 \pm 0.283 \mathrm{~g} / \mathrm{L}$ and productivity of $0.67 \pm 0.004-1.22 \pm 0.005$, respectively while BK9-2 gave the highest lactic acid of $93.51 \pm 0.552 \mathrm{~g} / \mathrm{L}$ and productivity of $1.30 \mathrm{~g} / \mathrm{L} . \mathrm{h}$, respectively. B. coagulans strains have been isolated from evaporated milk, soils and lignin supplemented minimal medium (Skerman et al., 1980; Philip et al., 1998; Glaser and Venus, 2014). B.coagulans J112 produced L-lactic acid by fed-batch fermentation with $85 \mathrm{~g} / \mathrm{L}$ initial xylose and $55 \mathrm{~g} / \mathrm{L}$ xylose added after $7.5 \mathrm{~h}, 137.5 \mathrm{~g} / \mathrm{L}$ and lactic acid yielded $98 \%$ and a productivity of $4.4 \mathrm{~g} / \mathrm{L}$.h (optical purity $>99.5 \%$ ) (Ye et al., 2013) while B. coagulans strain IPE22 gave $46.12 \mathrm{~g}$ LA from $100 \mathrm{~g}$ dry wheat straw with a supplement of 10 $\mathrm{g} / \mathrm{L}$ corn steep liquid powder at the cellulose (Zhang et al., 2014).

The isolates in Group IV identified as Sporolactobacillus, only isolate NN2 could produce lactic acid using $120 \mathrm{~g} / \mathrm{L}$ of glucose while isolate NN3-1 was inhibited by substrate inhibition. NN2 produced D-lactic acid concentration $87.64 \pm 0.375 \mathrm{~g} / \mathrm{L}$, yield $0.83 \pm 0.000$ $\mathrm{g} / \mathrm{g}$, productivity of $1.22 \pm 0.005 \mathrm{~g} / \mathrm{L}$.h and optical purity of D-lactic acid $96.16 \%$ while NN3-1 produced highest final D-lactic acid $50.69 \pm 1.021 \mathrm{~g} / \mathrm{L}$, yield $0.51 \pm 1.021$, productivity $0.70 \pm 0.026 \mathrm{~g} / \mathrm{L}$.h and optical purity of Dlactic acid $98.8 \%$ when $80 \mathrm{~g} / \mathrm{L}$ of glucose was used. $S$. inulinus strain was reported as the potential D-lactic acid producer with highly optical purity (Fukushima et al., 2004) while S. laevolacticus DSM442 was reported as an excellent producer for D-lactic acid production ( $\mathrm{Li}$ et al., 2013). In this study, S. laevolacticus NN2 and $S$. spathodeae NN3-1 were found to produce D-lactic acid with high optical purity as mentioned above.

\section{CONCLUSION}

L-Lactic acid producing bacteria including $L$. lactis subsp. lactis, L. taiwanensis, E. hirae and B. coagulans strains were distributed in tree barks and soil whereas sporeforming $S$. laevolacticus and $S$. spathodeae strains that produced $D$-lactic acid were isolated from soils. The isolate $B$. coagulans BK9-1 produced L-lactic acid with high optical purity $(99.56 \%)$ while S. laevolacticus NN2 produced D-lactic acid with optical purity $96.16 \%$. These isolates will be the potential bacteria for L-lactic acid or Dlactic acid production in the further study.

\section{ACKNOWLEDGEMENT}

This study was supported by the Grant for International Research Integration: Research Pyramid, Ratchadaphiseksomphot Endowment Fund (GCURP_58_01_33_01), Chulalongkorn University.

\section{REFERENCES}

Chen, Y. S., Chang, C. H., Pan, S. F., Wang, L. T., Chang, Y. C., Wu, H. C. and Yanagida, F. (2013). Lactococcus taiwanensis sp. nov., a lactic acid bacterium isolated from fresh cummingcordia. International Journal of Systematic and Evolutionary Microbiology 63, 2405-2409.

Cock, L. S. and de Stouvenel, A. R. (2006). Lactic acid production by a strain of Lactococcus lactis subsp. lactis isolated from sugar cane plants. Electronic Journal of Biotechnology 9, 40-45.

Devriese, L., Baele, M. and Butaye, P. (2006). The Genus Enterococcus: Taxonomy. In: The Prokaryotes: A Handbook on the Biology of Bacteria. Dworkin, M., Falkow, S., Rosenberg,E., Schleifer,K.H. and Stackebrandt, E. (eds.). Vol. 4. Springer, New York. pp. 163-174. 
Farrow, J. A. E. and Collins, M. D. (1985). Enterococcus hirae, a new species that includes amino acid assay strain NCDO 1258 and strains causing growth depression in young chickens. International Journal of Systematic and Evolutionary Microbiology 35, 73-75.

Felsenstein, J. (1985). Confidence limits on phylogenies: An approach using the bootstrap. Evolution 39, 783791.

Fujii, T., Tomita, Y., Ikushima, S., Horie, A. and Fujiwara, D. (2015). Draft genome sequence of Lactococcus lactis subsp. lactis $\mathrm{JCM} 5805^{\top}$, a strain that induces plasmacytoid dendritic cell activation. Genome Announcements 3, e00113-15.

Fukushima, K., Sogo, K., Miura, S. and Kimura, Y. (2004). Production of D-lactic acid by bacterial fermentation of rice starch. Macromolecular Bioscience, 4, 1021-1027.

Gao, T. and Ho, K. P. (2013). L-lactic acid production by Bacillus subtilis MUR1 in continuous culture. Journal of Biotechnology 168, 646-651.

Glaser, R. and Venus, J. (2014). Screening of Bacillus coagulans strains in lignin supplemented minimal medium with high throughput turbidity measurements. Biotechnology Reports 4, 60-65.

Hujanen, M. and Linko, Y. Y. (1996). Effect of temperature and various nitrogen sources on $\mathrm{L}(+)$ lactic acid production by Lactobacillus casei. Applied Microbiology and Biotechnology 45, 307-313.

John, R. P., Anisha, G.S., Nampoothiri, K. M. and Pandey, A. (2009). Direct lactic acid fermentation: Focus on simultaneous saccharification and lactic acid production. Biotechnology Advances 27, 145-152.

Kim, O. S., Cho, Y. J., Lee, K., Yoon, S. H., Kim, M., Na, H., Park, S. C., Jeon, Y. S., Lee, J. H., Yi, H., Won, S. and Chun, J. (2012). Introducing EzTaxon-e: A prokaryotic 16S rRNA gene sequence database with phylotypes that represent uncultured species. International Journal of Systematic and Evolutionary Microbiology 62, 716-721.

Laopaiboon, P., Thani, A., Leelavatcharamas, V. and Laopaiboon, L. (2010). Acid hydrolysis of sugarcane bagasse for lactic acid production. Bioresource Technology 101, 1036-1043.

Li, Y., Wang, L., Ju, J., Yu, B. and Ma, Y. (2013). Efficient production of polymer-grade $\mathrm{d}$-lactate by Sporolactobacillus laevolacticus DSM442 with agricultural waste cotton seed as the sole nitrogen source. Bioresource Technology 142, 186-191.

Ludwig, W., Schleifer, K. H. and Whitman, W. B. (2009). Genus Sporolactobacillus. In: Bergey's Manual of Systematic Bacteriology, $2^{\text {nd }}$. De Vos, P., Garrity, G. M., Jones, D., Krieg, N. R., Ludwig, W., Rainey, F. A., Schleifer, K. H. and Whitman, W. B. (eds.). Vol. 3, Springer, New York. pp. 386-391.

Michelson, T., Kask, K., Jõgi, E., Talpsep, E., Suitso, I. and Nurk, A. (2006). L(+)-Lactic acid producer Bacillus coagulans SIM-7 DSM 14043 and its comparison with Lactobacillus delbrueckii ssp. lactis DSM 20073. Enzyme and Microbial Technology 39, 861-867.
Nakamura, L. K., Blumenstock, I. and Claus, D. (1988). Taxonomic study of Bacillus coagulans Hammer 1915 with a proposal for Bacillus smithii sp. nov. International Journal of Systematic and Evolutionary Microbiology 38, 63-73.

Philip, L., lyengar, L. and Venkobachar, C. (1998). $\mathrm{Cr}(\mathrm{VI})$ reduction by Bacillus coagulans isolated from contaminated soils. Journal of Environmental Engineering 124, 1165-1170.

Prasirtsak, B., Tanasupawat, S., Boonsombat, R., Kodama, K. and Thongchul, N. (2013). Characterization of lactic acid producing bacteria from Thai sources. Journal of Applied Pharmaceutical Science 3, 033-038.

Saitou, N. and Nei, M. (1987). The neighbor-joining method: A new method for reconstructing phylogenetic trees. Molecular Biology and Evolution 4, 406-425.

Skerman, V. B. D., McGowan, V. and Sneath, P. H. A. (1980). Approved lists of bacterial names. International Journal of Systematic Bacteriology 30, 225-420.

Sobrun, Y., Bhaw-Luximon, A., Jhurry, D. and Puchooa, D. (2012). Isolation of lactic acid bacteria from sugar cane juice and production of lactic acid from selected improved strains. Advances in Bioscience and Biotechnology 3, 398-407.

Tamura, K., Stecher, G., Peterson, D., Filipski, A. and Kumar, S. (2013). MEGA6: Molecular evolutionary genetics analysis version 6.0. Molecular Biology and Evolution 30, 2725-2729.

Tanasupawat, S., Ezaki,T., Suzuki, K. I., Okada, S., Komagata, K.and Kozaki, M. (1992). Characterization and identification of Lactobacillus pentosus and Lactobacillus plantarum strains from fermented foods in Thailand. Journal of General and Applied Microbiology 38, 121-134.

Tanasupawat, S., Okada, S. and Komagata, K. (1998). Lactic acid bacteria found in fermented fish in Thailand. Journal of General and Applied Microbiology 44, 193-200.

Thamacharoensuk, T., Thongchul, N., Taweechotipatr, M., Tolieng, V., Kodama, K. and Tanasupawat, S. (2013). Screening and characterization of lactic acid bacteria from animal faeces for probiotic properties. Thai Journal of Veterinary Medicine 43, 541-551.

Thamacharoensuk, T., Kitahara, M., Ohkuma, M., Thongchul, N. and Tanasupawat, S. (2015). Sporolactobacillus shoreae sp. nov. and Sporolactobacillus spathodeae sp. nov., two sporeforming lactic acid bacteria isolated from tree barks in Thailand. International Journal of Systematic and Evolutionary Microbiology 65, 1220-1226.

Wee, Y. J., Kim, J. N. and Ryu, H. W. (2006). Biotechnological production of lactic acid and its recent applications. Food Technology and Biotechnology 44, 163-172.

Xu, T. T., Bai, Z. Z., Wang, L. J. and He, B. F. (2010). Breeding of $D(-)$-lactic acid high producing strain by low-energy ion implantation and preliminary analysis 
of related metabolism. Applied Biochemistry and Biotechnology 160, 314-321.

Ye, L., Zhou, X., Hudari, M. S., Li, Z. and Wu, J. C. (2013). Highly efficient production of L-lactic acid from xylose by newly isolated Bacillus coagulans C106. Bioresource Technology 132, 38-44.

Yokaryo, H. and Tokiwa, Y. (2014). Isolation of alkaliphilic bacteria for production of high optically pure L-(+)-lactic acid. Journal of General and Applied Microbiology 60, 270-275.

Zhang, Y., Chen, X., Luo, J., Qi, B. and Wan, Y. (2014). An efficient process for lactic acid production from wheat straw by a newly isolated Bacillus coagulans strain IPE22. Bioresource Technology 158, 396-399. 